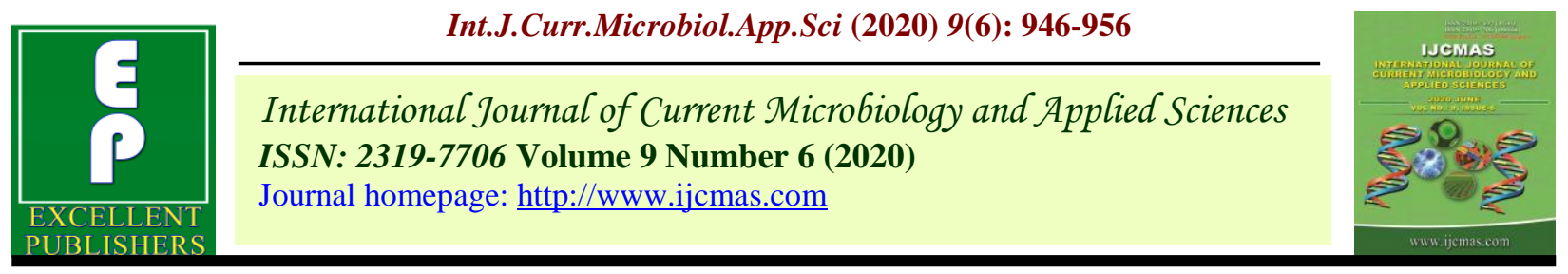

Original Research Article

https://doi.org/10.20546/ijcmas.2020.906.119

\title{
Effect of Sowing Dates and Foliar Spray of Urea on Yield Attributes and Yield of Maize Cultivars
}

\author{
Dinesh Kumar Jajoria $^{1 *}$, M. K. Kaushik ${ }^{2}$ and Shyam Sundar Sharma ${ }^{1}$ \\ ${ }^{1}$ SKN College of Agriculture, SKNAU, Jobner, India \\ ${ }^{2}$ Rajasthan College of Agriculture, MPUAT, Udaipur, India \\ *Corresponding author
}

\section{A B S T R A C T}

\begin{tabular}{|l|}
\hline Ke y w or d s \\
Maize, yield, urea, \\
foliar spray \\
\hline Article Info \\
\hline $\begin{array}{l}\text { Accepted: } \\
18 \text { May } 2020 \\
\text { Available Online: } \\
\text { 10 June } 2020\end{array}$ \\
\hline
\end{tabular}

An experiment was conducted during kharif season of two consecutive years 2013 and 2014 at the Instructional Farm, Rajasthan College of Agriculture, MPUAT, Udaipur to evaluate the effect of sowing dates and foliar spray of urea on yield attributes and yield of maize cultivars. The experiment was conducted with two sowing dates with four cultivar (Pratap HQPM - 1, Bio - 9637, Pratap Makka - 3 and Pratap Makka - 5) and three foliar spray (2\% urea, $4 \%$ urea and water spray). The experiment conducted in Split Plot Design (SPD) with three replications. The results showed that $25^{\text {th }}$ June sown maize recorded significantly higher yield attributing characters viz. cobs plant ${ }^{-1}$, grains $\operatorname{cob}^{-1}$ and 1000 grains weight as compared to $15^{\text {th }} \mathrm{July}$ sown maize. $25^{\text {th }}$ June sown maize also gave significantly higher grain yield $\left(4819 \mathrm{~kg} \mathrm{ha}^{-1}\right)$, stover yield $\left(8733 \mathrm{~kg} \mathrm{ha}^{-1}\right)$, biological yield $\left(13552 \mathrm{~kg} \mathrm{ha}^{-1}\right)$ as compared to $15^{\text {th }} \mathrm{July}$ sown maize. Amongst the cultivars of maize, Pratap HQPM-1 gave highest cob length, cob girth, grains cob ${ }^{-}$ , grains row $\mathrm{cob}^{-1}, 1000$ grains weight, grain yield $\left(5098 \mathrm{~kg} \mathrm{ha}^{-1}\right)$ and harvest index $(39.86 \%)$. Whereas, Pratap Makka - 3 gave maximum stover yield (9009 $\mathrm{kg} \mathrm{ha}^{-1}$ ) as compared to other maize cultivars. Foliar spray of $4 \%$ urea gave significantly higher 1000 grains weight and grain yield $\left(4739 \mathrm{~kg} \mathrm{ha}^{-1}\right)$ as compared to $2 \%$ foliar spray of urea and water spray. Application of 4 $\%$ urea also gave significantly grains $\mathrm{cob}^{-1}$, stover yield $\left(8668 \mathrm{~kg} \mathrm{ha}^{-1}\right)$ and biological yield $\left(13407 \mathrm{~kg} \mathrm{ha}^{-1}\right)$ as compared to water spray but found at par with $2 \%$ foliar spray of urea.

\section{Introduction}

Maize or corn (Zea mays) is one of the most important cereal crops cultivated globally. Maize is also known as 'Queen' of cereals because it has the highest genetic yield potential among the cereals. Maize occupies an important place in India due to its high potential for yield and greater demand for food, feed and industrial utilization. In India maize is grown over an area of 9.4 million hectares with the production of 24.4 million tonnes in year 2013-14 and ranks as the third in food grain production (Economic Survey, 2015). Average productivity of maize in India is $2676 \mathrm{~kg} \mathrm{ha}^{-1}$ and share of maize in total kharif food grain production is 16.62 per cent.

Maize is cultivated in almost all the states of India, but its extensive cultivation is confined to Karnataka, Andhra Pradesh, Maharashtra, Rajasthan, Tamil Nadu, Bihar, Uttar Pradesh, 
Madhya Pradesh, and Gujarat. Rajasthan occupies an area of 8.91 lakh hectares with a production of 15.51 lakh tones and productivity of $1740 \mathrm{~kg} \mathrm{ha}^{-1}$ (Agricultural Statistics, 2015). Rajasthan ranks $4^{\text {th }}$ in maize with 7.74 per cent share in overall production in India.

Maize like many other crops that are cultivated in the tropics is influenced by the environmental changes (temperature, rainfall, sunshine, wind, etc.) associated with different sowing dates.

Each maize variety has an optimum sowing date, and the wider the deviation from the optimum sowing date, the greater the yield loss.

Considerable yield decline as a result of sowing too early or too late have been reported in maize Beiragi et al., (2002). Khan et al., (2011) observed a negative effect of delayed sowing on yield components of maize. They noted that delayed sowing resulted in reduced number of grains per row, 1000 -grain weight and grain yield.

Meanwhile high demand of $\mathrm{N}$-fertilizer requirement which led to high leaching of nitrogen fertilizer through its high filtration rates. However, application of $\mathrm{N}$-fertilizer as urea foliar spray may decrease such losses.

El-Fouly and El-Sayed, (1995) reported that $\mathrm{N}$-losses from the recommended $\mathrm{N}$-dose for corn as a summer crop were 50\% through leaching and /or denitrification. In this connection, El-Fouly and Fawzi, (1996) mentioned that $\mathrm{N}$-losses in summer crops are very high and efficiency of $\mathrm{N}$-fertilizers used is very low. The objective of the present study was to investigate the effect of sowing dates and foliar spray of urea on different maize cultivars.

\section{Materials and Methods}

The experiment was conducted during kharif season of 2013 and 2014 at Instructional Farm, Rajasthan College of Agriculture, MPUAT, Udaipur. The experimental site is situated in the step foot of Aravali hills at $24^{0} 35^{\prime} \mathrm{N}$ latitude and $72^{\circ} 42^{\prime} \mathrm{E}$ longitude and at an elevation of $582.17 \mathrm{~m}$ above mean sea level. This region falls under agro-climatic zone IV- a (Sub-humid Southern Plains and Aravali Hills) of Rajasthan.

The soil of experimental field was clay loam in texture, slightly alkaline in reaction and calcareous in nature. It was medium in nitrogen and phosphorus and rich in available potassium. The experiment was laid out in split plot design with three replications, assigning 24 treatments consisting of two date of sowing $\left(25^{\text {th }}\right.$ June and $15^{\text {th }}$ July), four varieties (Pratap HQPM - 1, Bio - 9637, Pratap Makka - 3 and Pratap Makka - 5) as main plot treatments and three foliar spray (2 $\%$ urea, $4 \%$ urea and water spray) as sub plot treatment. The two foliar spray of urea (as per treatment) were applied at pre flowering stage and after 15 days of first spray. 2 and $4 \%$ urea solution were prepared by dissolving 20 and $40 \mathrm{~g}$ urea per litre of water, respectively. Data with respect to yield and yield attributes were carefully recorded from randomly selected plants.

\section{Results and Discussion}

\section{Yield attributes}

Data (Table 1) showed that normal sown crop $\left(25^{\text {th }}\right.$ June) registered significantly higher number of cobs plant ${ }^{-1}$ over late sown crop during both the years and on pooled data basis. In pooled data, normal sown crop recorded higher number of cobs plant $^{-1}$ by 6.86 per cent over late sown $\left(15^{\text {th }} \mathrm{July}\right)$ crop. 
The number of cob plant ${ }^{-1}$ was not significantly affected by cultivars and foliar spray of urea. Results presented in Table 1 revealed that the date of sowing and foliar spray of urea did not influence cob length. The maximum cob length was recorded under cultivar Pratap HQPM - 1 (14.96, 15.18 and $15.07 \mathrm{~cm}$ ) which was significantly superior over Bio - 9637 by 9.12, 8.90 and 9.04 per cent, Pratap Makka - 3 by 12.65, 12.11 and 12.38 per cent and Pratap Makka -5 by 13.16, 13.71 and 13.39 per cent during 2013, 2014 and pooled basis, respectively. However, cultivar Bio - 9637 (13.71, 13.94 and $13.82 \mathrm{~cm})$, Pratap Makka - 3 (13.28, 13.54 and $13.41 \mathrm{~cm}$ ) and Pratap Makka - 5 (13.22, 13.35 and $13.29 \mathrm{~cm}$ ) during 2013, 2014 and pooled basis, respectively were at par with each other.

Results (Table 1) showed that date of sowing and foliar spray of urea did not influence cob girth. But different cultivars of maize had significant variation in cob girth during both the years of the study. Maximum cob girth was recorded under cultivar Pratap HQPM - 1 (10.73 and $10.99 \mathrm{~cm}$ ) which was significantly superior by 9.60 and 8.93 per cent during 2013, 9.35 and 9.57 per cent during 2014 over Pratap Makka - 3 and Pratap Makka - 5, respectively but found at par with Bio - 9637 during both the years. However, on pooled data, Pratap HQPM - 1 also registered significantly higher cob girth over Bio 9637, Pratap Makka - 3 and Pratap Makka 5 by $4.83,9.48$ and 9.26 per cent, respectively. Bio - 9637 (10.23, 10.49 and $10.36 \mathrm{~cm})$, Pratap Makka - 3 9.79, 10.05 and $9.92 \mathrm{~cm}$ ) and Pratap Makka - 5 (9.85, 10.03 and 9.94 $\mathrm{cm})$ were at par with each other in respect to cob girth during both the years and pooled basis, respectively.

Data (Table 1) indicates that $25^{\text {th }}$ June sown crop produced higher number of grains $\mathrm{cob}^{-1}$ (403.26, 411.41and 407.33) which was significantly superior over $15^{\text {th }}$ July sown maize by $6.48,6.39$ and 6.43 per cent during both the years and their pooled basis, respectively. Maximum number of grain $\mathrm{cob}^{-1}$ was recorded under cultivar Pratap HQPM - 1 (420.86 and 424.00) which was significantly superior over Bio - 9637 by 5.46 and 5.24 per cent, Pratap Makka - 3 by 14.13 and 14.48 per cent and Pratap Makka -5 by 12.15 and 10.70 per cent during 2013 and on pooled basis. During 2014, Pratap HQPM - 1 also found superior over Pratap Makka - 3 and Pratap Makka - 5 by 14.83 and 9.31 per cent, respectively but found at par with Bio 9637.

As per pooled analysis, Bio 9637 produced higher number of grains $\mathrm{cob}^{-1}$ (402.31) which was significantly superior over Pratap Makka -3 and Pratap Makka - 5 by 8.59 and 5.00 per cent, respectively. Pratap Makka -3 and Pratap Makka - 5 were found at par with each other in respect to grains $\mathrm{cob}^{-1}$ during both the years and on pooled basis. Foliar spray of $4 \%$ urea on maize produced maximum number of grains $\mathrm{cob}^{-1}$ (400.71, 409.53 and 405.12) which was significantly superior over water spray by $6.18,7.09$ and 6.64 per cent during 2013, 2014 and their pooled analysis, respectively but found at par with foliar spray of $2 \%$ urea. Foliar spray of $2 \%$ urea (394.89, 405.23 and 400.06) also found significantly superior over water spray by $4.64,5.89$ and 5.31 per cent during 2013, 2014 and their pooled analysis, respectively.

The date of sowing and foliar spray of urea had no significant effect on number of grain rows $\mathrm{cob}^{-1}$. The highest number of grain rows $\mathrm{cob}^{-1}$ was recorded in cultivar Pratap HQPM 1 (14.3, 14.6 and 14.5) which was significantly superior over Pratap Makka -3 (12.7, 12.9 and 12.8) and Pratap Makka - 5 (12.6, 12.7 and 12.7) but found at par with Bio - 9637 (13.1, 13.3 and 13.2) during 2013, 2014 and pooled analysis, respectively. Bio 9637, Pratap Makka - 3 and Pratap Makka - 
5 found at par with each other in respect to number of grain rows $\operatorname{cob}^{-1}$ (Table 2). The crop sown on $25^{\text {th }}$ June was found significantly superior over $15^{\text {th }}$ July sown crop by $9.23,15.86$ and 12.54 per cent during 2013, 2014 and pooled basis, respectively with respect to 1000 grain weight. The maximum 1000 grain weight was recorded under cultivar Pratap HQPM - 1 (200.71, 199.54 and 200.12) which was significantly superior over Pratap Makka - 3 (175.36, 184.35 and $179.86 \mathrm{~g}$ ) and Pratap Makka - 5 $(182.83,187.52$ and $185.17 \mathrm{~g})$ but at par with Bio - 9637 (192.10, 1980.07 and $195.09 \mathrm{~g}$ ) during both the years and their pooled analysis. As per pooled analysis, the per cent increase in 1000 grains weight of cultivar Pratap HQPM -1 was 11.26 and 8.07 over Pratap Makka - 3 and Pratap Makka - 5, respectively. Bio - 9637 also found significantly superior over Pratap Makka - 3 by $9.55,7.44$ and 8.47 per cent but at par with Pratap Makka - 5 during 2013, 2014 and their pooled analysis, respectively. Whereas, Pratap Makka - 5 and Pratap Makka - 3 found at par with each other during both the years and their pooled analysis. The foliar spray of urea had significant improvement in 1000 grains weight during both the years and pooled study. Maximum 1000 grains weight was recorded with $4 \%$ foliar spray of urea which was found at par with $2 \%$ foliar spray of urea during both the years and on pooled basis. Whereas, foliar spray of $2 \%$ urea recorded significantly higher 1000 grain weight (188.83, 192.70 and 190.77) over water spray by $4.33,5.09$ and 4.72 per cent during 2003, 2014 and their pooled data, respectively (Table 2).

Data on 1000 grain weight presented in Table 3 show that there is a significant interaction among foliar spray and cultivars. Foliar spray of $4 \%$ urea on Pratap HQPM - 1 gave maximum 1000 grain weight $(211.12 \mathrm{~g})$ which was significantly superior over water spray on Pratap HQPM - 1 by 13.70 per cent but found at par with $2 \%$ foliar spray. Similarly, $4 \%$ foliar spray in Bio - 9637 also found significantly superior over water spray by 12.33 per cent. Whereas, Pratap Makka - 3 and Pratap Makka - 5 did not affect by foliar spray of water and urea.

Under $2 \%$ foliar spray of urea maximum 1000 grain weight (203.58 g) was recorded in Pratap HQPM - 1 which was significantly superior over Pratap Makka - 3 by 14.24 per cent but found at par with Bio - 9637 and pratap Makka - 5. Similarly, under $4 \%$ foliar spray of urea maximum 1000 grain weight (211.12 g) was recorded in Pratap HQPM - 1 which was significantly superior over Pratap Makka -3 and Pratap Makka - 5 by 14.37 and 13.34 per cent, respectively but found at par with Bio - 9637.

The marked improvement in various yield components of the crop seems to be on account of increased capacity of the normal sown crop to exploit environmental resources (above and below ground) for yield synthesis. Besides adequate supply of growth inputs (metabolites and nutrients), the congenial climatic conditions seems to have helped plants to exploit their potential for reproductive growth. It is well established that during reproductive phase, the interrelationship between assimilation organ, storage sites and growing organs are complex and depend on environmental conditions particularly temperature, which is main driving force determining duration and rate of grain growth. (Fischer, 1984). The significant increase in 1000 grain weight under $25^{\text {th }}$ June sown crop might be due to better uptake and translocation of photosynthetes during the reproductive phase of the crop, this increasing the size and weight of grains. Better expression of growth parameters and yield attributes might have contributed towards comparatively higher grain yield under $25^{\text {th }}$ 
June sown crop followed by $15^{\text {th }}$ July sown crop. This view is close conformity with the findings of Aziz et al., (2007), Feyzbakhsh et al., (2015) and Sulochana et al., (2015).

\section{Yields}

Table 4 showed that the date of sowing brought about significant variation in grain yield. Significantly higher grain yield was observed under $25^{\text {th }}$ June sown maize (4765, 4872 and $4819 \mathrm{~kg} \mathrm{ha}^{-1}$ ) as compared to $15^{\text {th }}$ July sown maize (4222, 4297 and $4259 \mathrm{~kg} \mathrm{ha}^{-}$ $\left.{ }^{1}\right)$ by $12.86,13.38$ and 13.14 per cent during 2013, 2014 and in pooled data, respectively. Pratap HQPM - 1 recorded highest grain yield of 5006, 5190 and $5098 \mathrm{~kg} \mathrm{ha}^{-1}$ which was significantly superior over Bio - 9637 (4604, 4735 and $4669 \mathrm{~kg} \mathrm{ha}^{-1}$ ), Pratap Makka - 3 (4141, 4158 and $4149 \mathrm{~kg} \mathrm{ha}^{-1}$ ) and Pratap Makka - 5 (4224, 4257 and $4240 \mathrm{~kg} \mathrm{ha}^{-1}$ ) during 2013, 2014 and their pooled basis, respectively. The magnitude of increases in grain yield of Pratap HQPM - 1 were in the order of $8.73,20.88$ and 18.51 per cent during $2013,9.61,24.82$ and 21.92 per cent during 2014 and 9.19, 22.87 and 20.24 per cent on pooled basis over Bio - 9637, Pratap Makka 3 and Pratap Makka - 5, respectively. During the year 2013, Bio - 9637 also gave significantly higher grain yield over Pratap Makka - 3 by 11.18 per cent but found at per with Pratap Makka - 5. Whereas, during 2014 and pooled analysis, Bio - 9637 gave significantly higher grain yield over Pratap Makka - 3 by 13.88 and 12.53 per cent and Pratap Makka - 5 by 11.22 and 10.12 per cent, respectively. Pratap Makka - 3 and Pratap Makka - 5 found at par with each other during 2013, 2014 and on pooled basis. Foliar spray of $4 \%$ urea on maize produced highest grain yield (4679, 4799 and $4739 \mathrm{~kg} \mathrm{ha}^{-1}$ ) which was significantly superior over water spray by $9.19,10.58$ and 9.90 per cent during 2013, 2014 and their pooled analysis, respectively but found at par with foliar spray of $2 \%$ urea. Foliar spray of $2 \%$ urea (4516, 4615 and $4566 \mathrm{~kg} \mathrm{ha} \mathrm{ha}^{-1}$ also found significantly superior over water spray by 5.39, 6.34 and 5.89 per cent during both the years and their pooled analysis, respectively.

A critical examination of data presented in Table 5 indicates that interaction effect of date of sowing, cultivars and foliar spray of water and urea was found significant on grain yield of maize. The maximum grain yield was recorded by $25^{\text {th }}$ June sown Pratap HQPM - 1 with $4 \%$ foliar spray of urea $\left(5808 \mathrm{~kg} \mathrm{ha}^{-1}\right)$ which was significantly superior over all other treatment combinations except $2 \%$ foliar spray of urea on $25^{\text {th }}$ June sown Pratap HQPM -1 and $4 \%$ foliar spray of urea on $25^{\text {th }}$ June sown Bio -9637 . The minimum grain yield (3418 $\mathrm{kg} \mathrm{ha}^{-1}$ ) was recorded under $15^{\text {th }}$ July sown Pratap Makka - 3 with $2 \%$ foliar spray of urea.

$25^{\text {th }}$ June sown crop produced higher stover yield $\left(8617,8850\right.$ and $8733 \mathrm{~kg} \mathrm{ha}^{-1}$ ) which was significantly superior over $15^{\text {th }}$ July sown maize by $8.14,10.75$ and 9.42 per cent during both the years and their pooled basis, respectively. Amongst cultivars, highest stover yield was recorded under Pratap Makka - 3 (8909, 9109 and $9009 \mathrm{~kg} \mathrm{ha}^{-1}$ ) which was significantly superior over Pratap HQPM - 1 by $15.94,18.13$ and 17.03 per cent and Bio -9637 by $12.25,11.80$ and 12.02 per cent but at par with Pratap Makka - 5 during 2013, 2014 and on pooled basis, respectively. As per pooled analysis, Pratap Makka - 5 (8681 $\mathrm{kg} \mathrm{ha}^{-1}$ ) also found significantly superior over Pratap HQPM - 1 and Bio 9637 by 12.77 and 7.95 per cent, respectively. Whereas, Pratap Makka - 3 and Pratap Makka - 5 found at par with each other during both the years and on pooled basis. Maximum stover yield was observed by $4 \%$ foliar spray of urea $(8584,8752$ and $8668 \mathrm{~kg}$ $\mathrm{ha}^{-1}$ ) which was significantly superior by $8.49,9.80$ and 9.14 per cent over water spray 
but found at par with $2 \%$ foliar spray of urea during 2013, 2014 and their pooled basis, respectively. $2 \%$ foliar spray of urea (8384, 8539 and $8462 \mathrm{~kg} \mathrm{ha}^{-1}$ ) was also found significantly superior over water spray by 5.95, 7.13 and 6.55 per cent during both the years and their pooled analysis.

Data (Table 6) showed that interaction effect between date of sowing and cultivars was found significant for stover yield. Maximum stover yield was recorded in cultivar Pratap Makka - 5 sown under $25^{\text {th }}$ June $(9227 \mathrm{~kg}$ ha $\left.{ }^{1}\right)$ which was significantly superior over that sown under $15^{\text {th }}$ July by 13.42 per cent. Similarly, 25 ${ }^{\text {th }}$ June sown Bio - 9637 (8800 $\mathrm{kg} \mathrm{ha}^{-1}$ ) also gave significantly higher stover yield over that sown at $15^{\text {th }}$ July. However, no significant effect of date of sowing was observed in Pratap HQPM - 1 and Pratap Makka - 3 .

Pratap Makka - 5 sown under $25^{\text {th }}$ June recorded maximum stover yield $(9227 \mathrm{~kg}$ ha 1) which was significantly superior over Pratap HQPM - 1 by 19.20 per cent but found at par with Bio - 9637 and Pratap Makka - 3 . Similarly, Pratap Makka - 3 and Bio - 9637 also found significantly superior over HQPM -1 by 18.38 and 13.68 per cent, respectively. Bio - 9637, Pratap Makka - 3 and Pratap Makka - 5 found statistically at par with each other when sown on $25^{\text {th }}$ June. Whereas, under $15^{\text {th }}$ July sowing date, Pratap Makka - 3 $\left(8854 \mathrm{~kg} \mathrm{ha}^{-1}\right)$ recorded higher stover yield which was significantly superior over Pratap HQPM - 1, Bio - 9637, and Pratap Makka 5 by $15.68,21.57$ and 8.84 per cent, respectively. Pratap Makka - $5\left(8135 \mathrm{~kg} \mathrm{ha}^{-1}\right)$ sown at $15^{\text {th }}$ July also gave significantly higher stover yield over Bio - 9637 but found at par with Pratap HQPM - 1 .

Date of sowing brought about significant variation in biological yield. Significantly higher biological yield was observed under $25^{\text {th }}$ June sown maize (13382, 13722 and $13552 \mathrm{~kg} \mathrm{ha}^{-1}$ ) which was significantly superior over $15^{\text {th }}$ July sown maize by 9.75 , 11.66 and 10.71 per cent during both the years and for pooled data, respectively. The maximum biological yield was observed by cultivar Pratap Makka - 3 (13050, 13266 and $13158 \mathrm{~kg} \mathrm{ha}^{-1}$ ) followed by Pratap Makka - 5 (12869, 12973 and $\left.12921 \mathrm{~kg} \mathrm{ha}^{-1}\right)$, Pratap HQPM- 1(12690, 12901 and $\left.12795 \mathrm{~kg} \mathrm{ha}^{-1}\right)$ and Bio - 9637 (12541, 12880 and $12711 \mathrm{~kg}$ $\mathrm{ha}^{-1}$ ) but found at par with each other cultivars during both the years and their pooled analysis, respectively. Maximum biological yield was recorded with $4 \%$ foliar spray of urea $\left(13264,13550\right.$ and $\left.13407 \mathrm{~kg} \mathrm{ha}^{-1}\right)$ which was found at par with $2 \%$ foliar spray of urea during both the years and on pooled basis. However, foliar spray of $2 \%$ urea record significantly higher biological yield (12901, 13154 and $13028 \mathrm{~kg} \mathrm{ha}^{-1}$ ) over water spray by 5.76, 6.85 and 6.32 per cent during 2013, 2014 and their pooled data, respectively.

Table 7 showed that interaction effect between date of sowing and cultivars was found significant for biological yield. The maximum biological yield was recorded in cultivar Pratap Makka - 3 sown under $25^{\text {th }}$ June (13868 kg ha ${ }^{-1}$ ) which was significantly higher over that sown under $15^{\text {th }}$ July by 11.41 per cent. Similar results were also found for Pratap Makka - 5 and Bio - 9637 when change the date of sowing. But no significant effect of date of sowing was observed in Pratap HQPM - 1. Pratap Makka -3 sown under $25^{\text {th }}$ June recorded maximum biological yield which was significantly at par with all other cultivars sown at $25^{\text {th }}$ June. Whereas, under $15^{\text {th }}$ July sowing date, Pratap HQPM - 1 (12555 kg ha $\left.{ }^{-1}\right)$ recorded maximum biological yield which was significantly superior over Bio - 9637 by 7.66 per cent but found at par with Pratap Makka 3 and Pratap Makka - 5. 
Table.1 Effect of date of sowing, cultivars and foliar spray of urea on yield attributes of maize

\begin{tabular}{|c|c|c|c|c|c|c|c|c|c|}
\hline \multirow[t]{3}{*}{ Treatment } & \multicolumn{9}{|c|}{ Yield attributes } \\
\hline & \multicolumn{3}{|c|}{ Number of cobs plant ${ }^{-1}$} & \multicolumn{3}{|c|}{ Cob length $(\mathrm{cm})$} & \multicolumn{3}{|c|}{ Cob girth $(\mathrm{cm})$} \\
\hline & 2013 & 2014 & Pooled & 2013 & 2014 & Pooled & 2013 & 2014 & Pooled \\
\hline \multicolumn{10}{|l|}{ Date of Sowing } \\
\hline $25^{\text {th }}$ June & 1.08 & 1.11 & 1.09 & 13.85 & 14.09 & 13.97 & 10.24 & 10.50 & 10.37 \\
\hline $15^{\text {th }}$ July & 1.00 & 1.04 & 1.02 & 13.73 & 13.91 & 13.82 & 10.07 & 10.28 & 10.17 \\
\hline SEm \pm & 0.02 & 0.02 & 0.01 & 0.28 & 0.28 & 0.20 & 0.15 & 0.17 & 0.11 \\
\hline $\mathrm{CD}(\mathrm{P}=0.05)$ & 0.05 & 0.07 & 0.04 & NS & NS & NS & NS & NS & NS \\
\hline \multicolumn{10}{|l|}{ Cultivars } \\
\hline Pratap HQPM - 1 & 1.06 & 1.11 & 1.09 & 14.96 & 15.18 & 15.07 & 10.73 & 10.99 & 10.86 \\
\hline Bio - 9637 & 1.05 & 1.11 & 1.08 & 13.71 & 13.94 & 13.82 & 10.23 & 10.49 & 10.36 \\
\hline Pratap Makka - 3 & 1.02 & 1.02 & 1.02 & 13.28 & 13.54 & 13.41 & 9.79 & 10.05 & 9.92 \\
\hline Pratap Makka - 5 & 1.02 & 1.05 & 1.03 & 13.22 & 13.35 & 13.29 & 9.85 & 10.03 & 9.94 \\
\hline $\operatorname{SEm} \pm$ & 0.02 & 0.03 & 0.02 & 0.40 & 0.39 & 0.28 & 0.21 & 0.24 & 0.15 \\
\hline $\mathrm{CD}(\mathrm{P}=0.05)$ & NS & NS & NS & 1.21 & 1.19 & 0.81 & 0.64 & 0.72 & 0.46 \\
\hline \multicolumn{10}{|l|}{ Foliar Spray } \\
\hline $2 \%$ Urea & 1.04 & 1.08 & 1.06 & 13.76 & 13.99 & 13.88 & 10.17 & 10.49 & 10.33 \\
\hline $4 \%$ Urea & 1.06 & 1.10 & 1.08 & 13.86 & 14.08 & 13.97 & 10.20 & 10.45 & 10.32 \\
\hline Water Spray & 1.02 & 1.04 & 1.03 & 13.75 & 13.93 & 13.84 & 10.08 & 10.23 & 10.15 \\
\hline $\mathrm{SEm} \pm$ & 0.02 & 0.03 & 0.02 & 0.28 & 0.31 & 0.21 & 0.14 & 0.16 & 0.11 \\
\hline $\mathrm{CD}(\mathrm{P}=0.05)$ & NS & NS & NS & NS & NS & NS & NS & NS & NS \\
\hline
\end{tabular}


Table.2 Effect of date of sowing, cultivars and foliar spray of urea on yield attributes of maize

\begin{tabular}{|c|c|c|c|c|c|c|c|c|c|}
\hline \multirow[t]{3}{*}{ Treatment } & \multicolumn{9}{|c|}{ Yield attributes } \\
\hline & \multicolumn{3}{|c|}{ Number of grains $\operatorname{cob}^{-1}$} & \multicolumn{3}{|c|}{ Number of grains row cob $^{-1}$} & \multicolumn{3}{|c|}{1000 grain weight $(\mathrm{g})$} \\
\hline & 2013 & 2014 & Pooled & 2013 & 2014 & Pooled & 2013 & 2014 & Pooled \\
\hline \multicolumn{10}{|l|}{ Date of Sowing } \\
\hline $25^{\text {th }}$ June & 403.26 & 411.41 & 407.33 & 13.2 & 13.5 & 13.4 & 196.03 & 206.51 & 201.27 \\
\hline $15^{\text {th }}$ July & 378.72 & 386.70 & 382.71 & 13.1 & 13.3 & 13.2 & 179.47 & 178.24 & 178.85 \\
\hline $\mathrm{SEm} \pm$ & 4.57 & 5.77 & 3.68 & 0.3 & 0.3 & 0.2 & 2.96 & 2.86 & 2.06 \\
\hline $\mathrm{CD}(\mathrm{P}=\mathbf{0 . 0 5})$ & 13.85 & 17.51 & 10.66 & NS & NS & NS & 8.97 & 8.66 & 5.96 \\
\hline \multicolumn{10}{|l|}{ Cultivars } \\
\hline Pratap HQPM - 1 & 420.86 & 427.42 & 424.14 & 14.3 & 14.6 & 14.5 & 200.71 & 199.54 & 200.12 \\
\hline Bio-9637 & 399.08 & 405.54 & 402.31 & 13.1 & 13.3 & 13.2 & 192.10 & 198.07 & 195.09 \\
\hline Pratap Makka - 3 & 368.75 & 372.22 & 370.48 & 12.7 & 12.9 & 12.8 & 175.36 & 184.35 & 179.86 \\
\hline Pratap Makka - 5 & 375.28 & 391.03 & 383.15 & 12.6 & 12.7 & 12.7 & 182.83 & 187.52 & 185.17 \\
\hline SEm \pm & 6.46 & 8.16 & 5.21 & 0.4 & 0.4 & 0.3 & 4.18 & 4.04 & 2.91 \\
\hline CD $(P=0.05)$ & 19.59 & 24.77 & 15.08 & 1.3 & 1.2 & 0.8 & 12.69 & 12.25 & 8.42 \\
\hline \multicolumn{10}{|l|}{ Foliar Spray } \\
\hline $2 \%$ Urea & 394.89 & 405.23 & 400.06 & 13.1 & 13.4 & 13.3 & 188.83 & 192.70 & 190.77 \\
\hline $4 \%$ Urea & 400.71 & 409.53 & 405.12 & 13.2 & 13.5 & 13.4 & 193.42 & 201.04 & 197.23 \\
\hline Water Spray & 377.37 & 382.40 & 379.88 & 13.1 & 13.3 & 13.2 & 180.99 & 183.37 & 182.18 \\
\hline $\mathrm{SEm} \pm$ & 5.74 & 6.81 & 4.46 & 0.3 & 0.3 & 0.2 & 2.52 & 2.82 & 1.89 \\
\hline $\mathrm{CD}(\mathrm{P}=\mathbf{0 . 0 5})$ & 16.54 & 19.63 & 12.59 & NS & NS & NS & 7.26 & 8.11 & 5.34 \\
\hline
\end{tabular}

Table.3 Interaction effect of cultivars and foliar spray on 1000 grain weight (pooled)

\begin{tabular}{|c|c|c|c|c|}
\hline \multirow[b]{2}{*}{ Foliar spray of urea } & \multicolumn{4}{|c|}{ Cultivars } \\
\hline & Pratap HQPM - 1 & Bio -9637 & Pratap Makka - 3 & Makka - 5 \\
\hline $2 \%$ Urea & 203.58 & 194.08 & 178.20 & 187.21 \\
\hline $4 \%$ Urea & 211.12 & 206.95 & 184.60 & 186.27 \\
\hline \multirow{2}{*}{ Water spray } & 185.68 & 184.23 & 176.77 & 182.04 \\
\hline & & & SEm \pm & $\mathrm{CD}(\mathrm{P}=0.05)$ \\
\hline \multicolumn{3}{|c|}{ Same foliar spray for different cultivars } & 6.30 & 18.08 \\
\hline \multicolumn{3}{|c|}{ Same cultivars for different foliar spray } & 5.34 & 15.10 \\
\hline
\end{tabular}


Table.4 Effect of date of sowing, cultivars and foliar spray of urea on grain, stover and biological yield of maize

\begin{tabular}{|c|c|c|c|c|c|c|c|c|c|}
\hline \multirow[t]{3}{*}{ Treatment } & \multicolumn{9}{|c|}{ Yields $\left(\mathrm{kg} \mathrm{ha}^{-1}\right)$} \\
\hline & \multicolumn{3}{|c|}{ Grain } & \multicolumn{3}{|c|}{ Stover } & \multicolumn{3}{|c|}{ Biological } \\
\hline & 2013 & 2014 & Pooled & 2013 & 2014 & Pooled & 2013 & 2014 & Pooled \\
\hline \multicolumn{10}{|l|}{ Date of Sowing } \\
\hline $25^{\text {th }}$ June & 4765 & 4872 & 4819 & 8617 & 8850 & 8733 & 13382 & 13722 & 13552 \\
\hline $15^{\text {th }}$ July & 4222 & 4297 & 4259 & 7971 & 7991 & 7981 & 12193 & 12289 & 12241 \\
\hline $\mathrm{SEm} \pm$ & 90 & 93 & 65 & 108 & 131 & 85 & 127 & 161 & 102 \\
\hline $\mathrm{CD}(\mathrm{P}=\mathbf{0 . 0 5})$ & 274 & 282 & 188 & 326 & 397 & 246 & 384 & 487 & 296 \\
\hline \multicolumn{10}{|l|}{ Cultivars } \\
\hline Pratap HQPM - 1 & 5006 & 5190 & 5098 & 7684 & 7711 & 7698 & 12690 & 12901 & 12795 \\
\hline Bio - 9637 & 4604 & 4735 & 4669 & 7937 & 8146 & 8042 & 12541 & 12880 & 12711 \\
\hline Pratap Makka - 3 & 4141 & 4158 & 4149 & 8909 & 9109 & 9009 & 13050 & 13266 & 13158 \\
\hline Pratap Makka - 5 & 4224 & 4257 & 4240 & 8645 & 8717 & 8681 & 12869 & 12973 & 12921 \\
\hline $\mathrm{SEm} \pm$ & 128 & 132 & 92 & 152 & 185 & 120 & 179 & 227 & 145 \\
\hline $\mathrm{CD}(\mathrm{P}=0.05)$ & 387 & 399 & 266 & 462 & 562 & 347 & NS & NS & NS \\
\hline \multicolumn{10}{|l|}{ Foliar Spray } \\
\hline $2 \%$ Urea & 4516 & 4615 & 4566 & 8384 & 8539 & 8462 & 12901 & 13154 & 13028 \\
\hline $4 \%$ Urea & 4679 & 4799 & 4739 & 8584 & 8752 & 8668 & 13264 & 13550 & 13407 \\
\hline Water Spray & 4285 & 4340 & 4312 & 7913 & 7971 & 7942 & 12198 & 12311 & 12254 \\
\hline SEm \pm & 78 & 116 & 70 & 154 & 173 & 116 & 176 & 217 & 140 \\
\hline $\mathrm{CD}(\mathrm{P}=\mathbf{0 . 0 5})$ & 225 & 335 & 198 & 444 & 499 & 328 & 507 & 624 & 394 \\
\hline
\end{tabular}

Table.5 Interaction effect of date of sowing, cultivars and foliar spray on grain yield of maize (pooled)

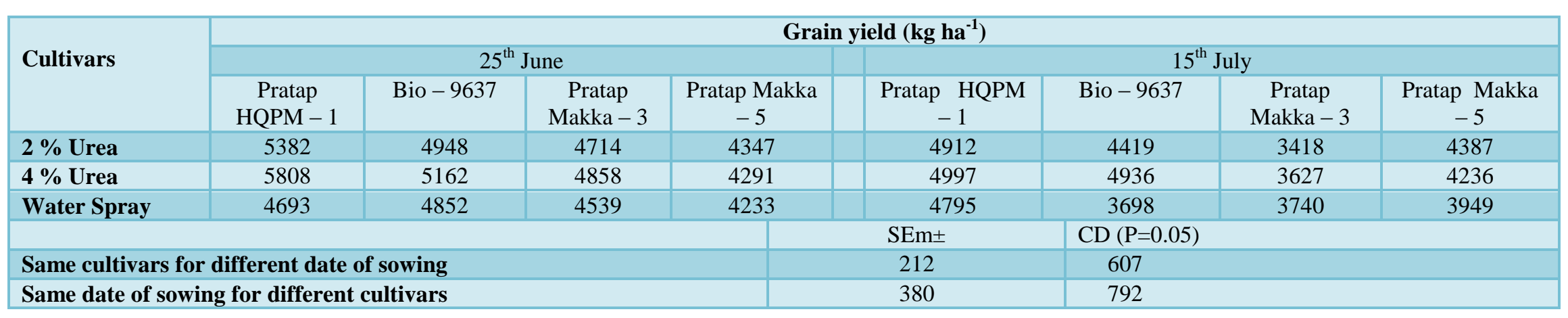


Table.6 Interaction effect of date of sowing and cultivars on stover yield $\left(\mathrm{kg} \mathrm{ha}^{-1}\right)$ of maize (pooled)

\begin{tabular}{|l|c|c|}
\hline \multirow{2}{*}{ Cultivars } & \multicolumn{2}{|c|}{ Date of sowing } \\
\hline Pratap HQPM - 1 & $25^{\text {th }}$ June & $15^{\text {th }}$ July \\
\hline Bio - 9637 & 7741 & 7654 \\
\hline Pratap Makka - 3 & 8800 & 7283 \\
\hline Pratap Makka - 5 & 9164 & 8854 \\
\hline \multicolumn{2}{|l|}{} & \multicolumn{2}{|c|}{8135} \\
\hline Same cultivars for different date of sowing & 254 & CD $(\mathrm{P}=0.05)$ \\
\hline Same date of sowing for different cultivars & 240 & 694 \\
\hline
\end{tabular}

Table.7 Interaction effect of date of sowing and cultivars on biological yield $\left(\mathrm{kg} \mathrm{ha}^{-1}\right)$ of maize (pooled)

\begin{tabular}{|c|c|c|c|}
\hline \multirow[b]{2}{*}{ Cultivars } & \multicolumn{3}{|c|}{ Date of sowing } \\
\hline & $25^{\text {th }}$ June & \multicolumn{2}{|c|}{$15^{\text {th }}$ July } \\
\hline Pratap HQPM - 1 & 13036 & \multicolumn{2}{|c|}{12555} \\
\hline Bio -9637 & 13788 & \multicolumn{2}{|c|}{11634} \\
\hline Pratap Makka - 3 & 13868 & \multicolumn{2}{|c|}{12448} \\
\hline Pratap Makka - 5 & 13517 & \multicolumn{2}{|c|}{12326} \\
\hline & & SEm \pm & $\mathrm{CD}(\mathrm{P}=0.05)$ \\
\hline \multicolumn{2}{|c|}{ Same cultivars for different date of sowing } & 306 & 875 \\
\hline \multicolumn{2}{|c|}{ Same date of sowing for different cultivars } & 289 & 838 \\
\hline
\end{tabular}

Yields are directly related to yield attributes. Thus, higher grain yield could be ascribed to the fact that yield of the crop is a function of yield attributes which are dependent on complementary interactions between vegetative and reproductive growth of the crop.

Their overall effects reflect in the form of yield.This view is close conformity with the findings of Aziz et al., (2007), Feyzbakhsh et al., (2015) and Sulochana et al., (2015).

On the basis of present study it could be concluded that under prevailing agroclimatic conditions, maize cultivar Pratap HQPM - 1 sown on $25^{\text {th }}$ June with $4 \%$ foliar spray gave maximum grain yield (5808 $\left.\mathrm{kg} \mathrm{ha}^{-1}\right)$.

\section{References}

Agricultural statistics, 2015. Directorate of Economics and Statistics, Department of Agriculture and Co-operation, Rajasthan.

Aziz, H., Rehman, H., and Khan, N. 2007. Maize cultivar response to population density and planting date for grain and biomass yield. Sarahad Journal of Agriculture23: 25-30.

Beiragi MA, Khorasani SK, Shojaei SH, Dadresan M, Mostafavi K, Golbashy A. Study on Planting Dates on Growth and Yield of 18 Corn Hybrids (Zea mays L.). American Journal of Experimental Agriculture. 2011;1(3):110-120.

Economic Survey, 2015. Ministry of Finance, Government of India. 
El-Fouly, M.M. and El-Sayed, A.A. 1995. Nitrogen balance in some major field crops in Egypt. Proceeding of Seminar "Production and use of Chemical Fertilizers and Environment" pp. 93-99.

El-Fouly, M.M. and Fawzi, A.F.A. 1996. Higher and better yields with less environmental pollution in Egypt through balanced fertilizer use. Fertilizer Research43: 1-4.

Feyzbakhsh M. T., Kamkar B., Mokhtarpour H. and Asadi M. E. 2015. Effect of soil water management and different sowing dates on maize yield and water use efficiency under drip irrigation system. Archives of Agronomy and Soil Science61: 1581-1592.

Khan MM. Effect of planting patterns on the growth, yield and quality of two maize hybrids. M.Sc. (Hons.) Thesis, Dept. Agronomy. University of Agriculture. Faisalabad; 2002.

Sulochana, Solanki N. S., Dhewa J. S. and Bajia R. 2015. Effect of sowing dates on growth, phenology and agro meteorological indices for maize varieties. The Bioscan 10 : 1339-1343.

\section{How to cite this article:}

Dinesh Kumar Jajoria, M. K. Kaushik and Shyam Sundar Sharma. 2020. Effect of Sowing Dates and Foliar Spray of Urea on Yield Attributes and Yield of Maize Cultivars. Int.J.Curr.Microbiol.App.Sci. 9(06): 946-956. doi: https://doi.org/10.20546/ijcmas.2020.906.119 